\title{
Recent advances in developing disease resistance in plants
}

\section{[version 1; peer review: 2 approved]}

\author{
Anuj Sharma (D), Jeffrey B. Jones (D), Frank F. White (iD)
}

Department of Plant Pathology, University of Florida, Gainesville, FL, USA

V1 First published: 19 Nov 2019, 8(F1000 Faculty Rev):1934

https://doi.org/10.12688/f1000research.20179.1

Latest published: 19 Nov 2019, 8(F1000 Faculty Rev):1934

https://doi.org/10.12688/f1000research.20179.1

\section{Abstract}

Approaches to manipulating disease resistance in plants is expanding exponentially due to advances in our understanding of plant defense mechanisms and new tools for manipulating the plant genome. The application of effective strategies is only limited now by adoption of rapid classical genetic techniques and the acceptance of genetically engineered traits for some problems. The use of genome editing and cis-genetics, where possible, may facilitate applications that otherwise require considerable time or genetic engineering, depending on settling legal definitions of the products. Nonetheless, the variety of approaches to developing disease resistance has never been greater.

Keywords

$\mathrm{R}$ genes, disease resistance, genome editing

\section{Open Peer Review \\ Approval Status \\ 1 \\ 2 \\ version 1 \\ 19 Nov 2019 \\ Faculty Reviews are review articles written by the prestigious Members of Faculty Opinions. The articles are commissioned and peer reviewed before publication to ensure that the final, published version is comprehensive and accessible. The reviewers who approved the final version are listed with their names and affiliations.}

\section{Zuhua He, National Key Laboratory of Plant Molecular Genetics, CAS Center for Excellence in Molecular Plant Sciences/Shanghai Institute of Plant Physiology \& Ecology, Chinese Academy of Sciences, Shanghai, China \\ 2. Magdy M Mahfouz, King Abdullah University of Science and Technology, Thuwal, Saudi Arabia}

Any comments on the article can be found at the end of the article. 
Corresponding author: Frank F. White (ffwhite@ufl.edu)

Author roles: Sharma A: Writing - Original Draft Preparation, Writing - Review \& Editing; Jones JB: Writing - Original Draft Preparation, Writing - Review \& Editing; White FF: Writing - Original Draft Preparation, Writing - Review \& Editing

Competing interests: FFW is an inventor on a provisional patent application 62832300 that covers EBE-edited rice lines. AS and JBJ declare that they have no competing interests.

Grant information: FFW gratefully acknowledge funding, in part, from the Bill and Melinda Gates Foundation to Heinrich Heine University, Düsseldorf, and subaward to University of Florida and the National Science Foundation (1741090). Any opinions expressed in the manuscript are the opinions of the authors and do not represent positions of the foundations or agencies.

The funders had no role in study design, data collection and analysis, decision to publish, or preparation of the manuscript.

Copyright: ( 2019 Sharma A et al. This is an open access article distributed under the terms of the Creative Commons Attribution License, which permits unrestricted use, distribution, and reproduction in any medium, provided the original work is properly cited.

How to cite this article: Sharma A, Jones JB and White FF. Recent advances in developing disease resistance in plants [version 1; peer review: 2 approved] F1000Research 2019, 8(F1000 Faculty Rev):1934 https://doi.org/10.12688/f1000research.20179.1

First published: 19 Nov 2019, 8(F1000 Faculty Rev):1934 https://doi.org/10.12688/f1000research.20179.1 
Genetic resistance represents the most economical approach to crop protection, and one goal of understanding plant/pathogen interactions at the molecular level is to facilitate disease resistance in crop species. Disease resistance is often the most dynamic component of the crop breeding process, requiring continual updating owing to pathogen adaptation to plant genotypes. An ancillary goal is to engineer resistance that is broad (effective against most or all genotypes of the pathogen) and durable (lasting through many cropping seasons). Research continues to unveil details and mechanisms that function to enable pathogens to parasitize plants and how plants defend themselves against parasitism. Increasingly, the knowledge is being implemented in strategies to enhance resistance to pathogens in crop species and to expedite resistance breeding in the field. Creative transgenic approaches continue to be explored, and the more recent genome editing tools have expanded the approaches to engineering resistance. Nonetheless, advances are needed in understanding how basic endogenous defense components work together and in generating novel resistances with components of the defense system.

Heterologous expression of pattern recognition receptors (PRRs), which recognize conserved molecules in pathogens or the products of pathogen-mediated degradation of host molecules and trigger immune responses to a wide range of pathogens, continues to be applied to a widening range of species, particularly those with recalcitrant disease issues ${ }^{1}$. Elongation Factor-Tu Receptor (EFR) is a PRR that was identified in Arabidopsis and recognizes EF-Tu, a highly conserved abundant protein in prokaryotes $^{2}$. Many crop species apparently lack this specific or analogous receptor despite the conserved nature of EF-Tu. Transfer of AtEFR from Arabidopsis to tobacco and tomato, in particular, reduced disease severity in the field due to two bacterial pathogens with very different life styles, namely Ralstonia solanacearum and Xanthomonas perforans, the causal agents of bacterial southern wilt and bacterial spot, respectively ${ }^{3,4}$. Similar results have been reported for potato ${ }^{5}$. AtEFR also triggered immunity in wheat upon challenge with Pseudomonas syringae pv. oryzae ${ }^{6}$. However, transfer of AtEFR to rice did not make the lines more resistant to the most prevalent pathogen, Xanthomonas oryzae pv. oryzae (Xoo), unless the elicitor portion of EF-TU was applied prior to infection ${ }^{7,8}$. Transfer of another PRR, Flagellin Sensitive 2 (FLS2) from Nicotiana, to sweet orange reduced susceptibility to citrus canker9. Use of the PRR gene Xa21 continues to be expanded. Xa21 of rice produces a receptor kinase that recognizes a small sulfonated peptide ( $\operatorname{RaxX}$ ) synthesized by $\mathrm{Xoo}$ and some related species and confers resistance to bacterial blight of rice ${ }^{10,11}$. The effectiveness of $\mathrm{Xa} 21$ is limited to diseases caused by Xanthomonas species that produce $\operatorname{RaxX}^{10}$. Fortunately, transfer of $X a 21$ to banana provides resistance to bacterial wilt, which is threatening banana and enset production in east Africa, because the pathogen, Xanthomonas vasicola pv. musacearum, also makes and processes $\operatorname{Rax}^{12}$.

The application of heterologous transfer of PRRs among species will be interesting. EFR and FLS2 were originally identified by the response to the isolated elicitor and do not provide complete resistance to infection due to bacterial virulence factors, which are capable of suppressing defense signaling by receptors ${ }^{13}$. Perhaps it is not surprising that the introduction of heterologous PRR genes corresponding to highly conserved elicitors does not always provide protection to crop species, as their pathogens may have already adapted to defense responses elicited by infection. On the other hand, it is striking, as noted above, that some bacterial pathogens do not suppress host immunity in the presence of the PRRs. Crop species, including tomato, may have lost some PRRs in the domestication and breeding process.

The largest family of resistance (R) genes encode the nucleotide binding site and leucine-rich repeat (NBS-LRR or NLR for short) proteins. Owing to their conservation and ease of identification, NLRs are closest to what might be called industrial-scale application, and NLR mining could potentially replace R-gene introgression from related but poorer quality germplasm and crosses with related species (wide crosses). NLR members (and the associated components, which often provide the pathogen recognition function) generally provide resistance against a specific subset of pathogens, or races, that express specific effector proteins, and the NLR complex often acts in a genefor-gene manner. More problematic is that the genes tend to function only within closely related species, possibly because of the adaptation to other components of the specific NLR complex. An early example was the transfer of the $B s 2$ gene for resistance to bacterial spot disease in pepper to tomato, which suffers disease from related pathogens ${ }^{4,14}$. The NLR gene $R G A 2$ for resistance to Fusarium was transferred from a resistant diploid banana species to Cavendish banana ${ }^{15}$. Another example is the transfer of an NLR from pigeon pea to soybean for resistance to soybean rust ${ }^{16}$. The success of transferring NLR genes between species has led to more extensive efforts of extracting NLR homologs (often referred to as $\mathrm{R}$ gene analogs or RGAs) from resistant species. $\mathrm{R}$ gene enrichment sequencing, or RenSeq, is a sequence capture technique for the enrichment of NLR sequences ${ }^{17}$. The underlying goal is to recover NLR family members from plants with known resistance and transfer candidates to the desired variety. Several variations of this method have been reported, including chemical mutagenesis of a line followed by sequence capture and association genetics of wild populations followed by sequence capture ${ }^{18,19}$. NLR capture from related species will facilitate the stacking of $\mathrm{R}$ genes against common core effectors of all extant pathogen genotypes and, consequentially, provide broad resistance. For example, the $B s 2$ gene, which targets the ubiquitous AvrBs2 effector of Xanthomonas, can be combined with Roq1, a new R gene from Nicotiana directed at the common effector XopQ, and other as-yet-unidentified NLRs directed toward other conserved effectors as identified in sequencing of large strain collections from infected plants ${ }^{20,21}$. Advances in NLR gene mining and gene transfer may have come none too soon and can be applied to wheat blast outbreaks ${ }^{22}$. Advancements in NLR applications will come from new methods to identify novel $\mathrm{R}$ genes in existing NLR libraries.

Research is also providing clues that promise to broaden the application of NLR resistance strategies and even the promise of generating NLR libraries with novel pathogen recognition 
properties de novo. Single NLR-related R gene transfer between distantly related species often fails, and broader application of NLRs will come from a greater understanding of NLR function. NLR-like $\mathrm{R}$ genes are simply the variable genetic component of NLR signaling complexes, which occur in a variety of forms. The complex can include a guarded protein, alternatively called guardee or sensor, and the sensor may be an integrated domain of the $\mathrm{NLR}^{23}$. The guardee may be a defense signaling protein or other component that is targeted by pathogens to enhance susceptibility. In some cases, the guardee has no apparent function other than to recognize the effector or effector activity of the pathogen. In the latter case, the guardee is referred to as a decoy. In a variety of cases, the components consist of a pair of NLR or NLR-like genes ${ }^{24}$. The NLRs RPS4 and RRS1, for example, are $\mathrm{R}$ genes from Arabidopsis and provide resistance against the bacteria Pseudomonas syringae and Ralstonia solanacearum, respectively. The RPS4/RRS1 pair is a remarkable case where the variation between resistance and susceptibility toward each of the two pathogens was based on separate components. However, both genes are, in fact, required for the resistance to each pathogen ${ }^{25}$. Furthermore, tomato plants expressing both RPS4 and RRS1 were resistant to both bacteria, and similar results were obtained for transgenic cucumber expressing RPS4/RRS1 against anthracnose ${ }^{26}$. Manipulation of the complexes may also allow changing the complex to recognize other pathogens. In the Arabidopsis-P. syringae system, the $\mathrm{R}$ gene $P B S 1$ product is perceived as a decoy working in concert with the NLR RPS5 and cleaved by the secreted bacterial protease effector AvrPphB. The cleavage of PSB1 is recognized by R-gene RPS5, resulting in the detection of bacteria and a resistance reaction ${ }^{27}$. A novel $P B S 1$ gene was created by substituting the cleavage site with cleavage site sequences that are recognized by other viral and secreted bacterial proteases ${ }^{28}$. When expressed together, the modified PBS1 genes conferred RPS5mediated resistance to new pathogens. Changes in the integrated sensor domain of the Pik group of NLRs directed at the rice blast pathogen effectors indicate that manipulation of the domain could produce new recognition motifs ${ }^{29}$. In the potatoPhytophthora infestans system, the resistance gene $R 3 a$ is activated by the RXLR effector, AVR $3 \mathrm{a}^{\mathrm{KI}}$, but not by the allelic product $\mathrm{AVR} 3 \mathrm{a}^{\mathrm{EM}}$, and, through random mutagenesis, a mutant version of $\mathrm{R} 3 \mathrm{a}$ was identified that recognized AVR $3 \mathrm{a}^{\mathrm{EM} 30}$. Interestingly, mutation in the same position in the $I 2$ gene, a homologue of the $R 3 a$ gene in tomato, made the gene more responsive to AVR3a and conferred partial resistance to $P$. infestans and expanded the gene's effectiveness to an additional fungal pathogen ${ }^{31}$. Recent studies of the structural changes that the NLR proteins themselves undergo upon elicitation may also provide insight for improved manipulation of this effector class ${ }^{32,33}$. Further utility of the NLR class will come from improved structural models and associated components and induced variation by gene targeting strategies $^{23}$.

Ectopic expression of defense-related, toxin, and other miscellaneous genes has always been a major part of the toolbox in engineering resistance. The approaches have been applied to recalcitrant disease problems and, in a variety of cases, have reached or completed confined field trial stage ${ }^{34}$. Secreted anti-microbial peptides (AMPs) are used in a variety of crop species $^{35}$. Cecropin is an AMP naturally produced by a moth, Hyalophora cecropia, that confers a broad spectrum of protection against a wide range of pathogens. Rice seed expressing cecropin A from endosperm-specific promoter exhibited resistance to infection by Fusarium verticillioides and Dickeya dadanti $^{36}$. A synthetic version of cecropin expressed in citrus was reported to be effective against the bacterium Candidatus Liberibacter asiaticus, the causal agent of huanglongbing $(\mathrm{HLB})^{37}$. Expression of de novo designed AMP SP1-1 in tomato fused with secretion of the signal from radish defensin provided resistance to bacterial spot ${ }^{38}$. Using pathogen physiology against itself has also provided promising results. Diffusible signal factor (DSF) is a mobile extracellular signal molecule produced by bacterial pathogens which controls cell densitydependent patterns of gene expression. In Xylella fastidiosa, DSF production is conferred by the gene $r p f F$. Ectopic production of DSF results in hypervirulence but decreases transmissibility by vectors owing to interference with bacterial gene regulation $^{39}$. Susceptible scion grafted to transgenic rootstock also displayed resistance to the pathogen in field trials. Similar reductions in disease severity were also observed by ectopic expression of $r p f F$ in citrus and tobacco ${ }^{40}$.

Strides in genome editing, particularly the CRISPR-Cas9 system, have increased interest towards the development of disease resistance through the modification of susceptible (S) genes of the plant ${ }^{41}$. The classic example is mlo, a recessive $\mathrm{R}$ gene of barley with resistance toward powdery mildew ${ }^{42}$. The null allele provides broad, durable resistance against the pathogen Blumeria graminis f. sp. hordei. Simultaneous editing of all three homoeoalleles of $M L O$ locus in hexaploid wheat conferred recessive resistance against powdery mildew in one generation $^{43}$. Disruption of downy mildew resistance-6 (DMR6) was originally identified in Arabidopsis and suppresses free salicylic acid (SA) levels ${ }^{44}$. Enhanced SA levels are associated with reduced susceptibility to a variety of pathogens, particularly bacterial pathogens. Mutations created by CRISPR-Cas9 in DMR6 orthologs in tomato were reported to confer resistance to a number of pathogens, including $P$. syringae pv. tomato, Phytophthora capsica, X. perforans, and Xanthomonas gardneri ${ }^{45}$. Modifications of the SA pathway adds to the widespread experimental utilization of ectopic expression of the SA receptor nonexpressor of pathogenesis related genes 1 (NPR1), which has been reviewed extensively ${ }^{46,47}$.

Diseases that involve transcription activator-like effectors (TALes) are excellent candidates for genome editing. TALes, which are deployed by many members of the bacterial genus Xanthomonas, function by binding to specific DNA sequences, known as effector binding elements (EBEs), in the promoters of $\mathrm{S}$ genes and promote heroic levels of $\mathrm{S}$ gene expression and, consequently through $\mathrm{S}$ gene product function, enhance disease susceptibility. Polymorphisms in EBEs by preventing TALe binding can provide recessive resistance in cases where TALes play a critical role in disease development. The citrus gene $C S L O B 1$ is a susceptibility factor for citrus canker induced by the TALe PthA4 of Xanthomonas citri. CRISPR-Cas9mediated modification in the EBE in the promoter region of 
CsLOB1 improved canker resistance and reduced canker development in sweet orange and grapefruit ${ }^{48-50}$. Bacterial blight of rice is highly dependent on TALe-mediated expression of sucrose transporters known as SWEET genes. Three SWEET genes are known to be targeted by strains of Xoo, and natural polymorphisms occur in the SWEET gene promoters that provide recessive resistance to some strains of the pathogen Xoo. OsSWEET14 is an $\mathrm{S}$ gene in rice for infections by Xoo. Mutations in the promoter EBE region for the TALe effectors AvrXa7 and PthXo3 using TALe nucleases (TALENs) led to loss of expression of $\mathrm{S}$ gene and resistance to strains depending on those two TALes for virulence ${ }^{51-53}$. The $\mathrm{S}$ gene OsSWEET13 is upregulated by TALes, leading to bacterial blight ${ }^{54}$. Modification of the promotor of OSSWEET13 rice by CRISPR-Cas9 treatment resulted in resistance against strains that require OSSWEET13 expression $^{54}$. Modification of all three genes simultaneously has been accomplished with CRISPR-Cas9 and provides broad resistance against extant strains ${ }^{55}$.

Disruption of S genes, by either editing or silencing, potentially comes with its own set of problems. First, these resistances are recessive, requiring homozygous mutant plants to screen for resistance. Second, these genes often have functional roles in the plant, and deletion or modification of expression may result in growth defects and/or loss of yield ${ }^{56}$. For example, a CRISPRCas9-mediated complete disruption of the OsSEC3A gene in rice caused enhanced defense response against blast caused by Magnaporthe oryzae. However, the resistant plant showed dwarf stature and lesion-mimic phenotype ${ }^{57,58}$. Similarly, the mutations in wheat $M L O$ conferred resistance against powdery mildew, but some mutants have been reported to have a leaf chlorosis phenotype similar to what is sometimes observed in barley $^{43,59}$.

The affinity of TALes to bind to specific EBE sequences can be hijacked for activation of resistance by TALes. $\mathrm{R}$ gene promoters have been modified to include a concatemer of EBE sites for TALes from multiple strains of a pathogen ${ }^{60,61}$. TAL EBEs can also be added to promoters to recruit TALe-mediated expression of autonomous $\mathrm{R}$ genes or avirulence proteins leading to resistance reactions ${ }^{62,63}$.

Because of their dependence on host functions, viruses are vulnerable to manipulations of host genes. Eukaryotic translation initiation factors (eIF4E) are essential for infection by singlestranded positive-sense RNA viruses ${ }^{64}$. They are also vital for normal initiation of translation in host cells. Due to the presence of two isoforms, null mutants of any one isoform can result in resistance to a number of viruses ${ }^{65,66}$. However, simultaneous knockout of both isoforms can lead to lethality or impaired growth ${ }^{67}$. Genome editing can be used to create novel functional alleles by mimicking natural variation of eIF4E in resistant plant species $^{68}$. These synthetic genes for elF4E confer resistance to viruses without affecting plant physiology.

Site-specific nucleases have also been deployed as functional components in plants for resistance against viruses. This approach imitates the viral immunity in prokaryotes in which the CRISPR system recognizes and cleaves the viral genome in vivo ${ }^{69}$. The CRISPR-Cas9 system expressed transiently in Nicotiana along with sgRNA that recognize the viral genome significantly reduced geminivirus accumulation not just in inoculated areas but also systemically ${ }^{70,71}$. The ability of viruses to overcome immunity is much lower when targeting intergenic regions compared to coding regions ${ }^{57}$. A powerful system to control multiple viruses in cotton leaf curl disease related to begomovirus complex can be achieved by multiplex CRISPR system, imitating CRISPR function in bacteria ${ }^{72}$.

The analyses of naturally occurring resistances, particularly cases of single gene broad $\mathrm{R}$ genes, has provided a remarkable variety of genes beyond the now-classic PRRs and NLRs. Wheat breeding and characterization of many wheat relatives has provided many broad, durable $\mathrm{R}$ gene candidates, and the characterization of a number of rust $\mathrm{R}$ genes of wheat warns us that knowledge of broad, durable resistance will likely come with considerable advances in our understanding of plant physiology. The broad R genes, Lr34 and Lr67, provide broad partial resistance to wheat leaf rust (Puccinia triticina) and to other pathogens, for example, yellow rust (Puccinia striiformis f. sp. tritici). The two genes were discovered to encode ABC-type and hexose transporters, respectively ${ }^{73,74}$. Despite the novel properties of the gene products, transfer of the genes, at least within the cereal family, indicates that the genes can function similarly in related species ${ }^{75-79}$. Lr67 appears to be impaired in sugar transport, while Lr34 product was shown recently to be capable of transporting abscisic acid (ABA) ${ }^{80}$. Whether these attributes are relevant to the broad and multi-pathogen resistance is unknown. At the same time, the functionality in related species indicates a conserved function.

Success of many of the advances in engineering disease resistance in crop species, of course, depends on societal acceptance of various approaches to plant genome modification. Ectopic expression of heterologous transgenes or silencing of genes generally comes under the guise of foreign DNA transfer and still faces considerable headwinds owing to acceptance and regulatory protocols. Modification of transgenic classifications, for example, the concept of cisgenics (allowing the addition of genes from a crossable species) as opposed to transgenics (the addition of a gene or genes from a non-crossable species), may increase the workable space in crop modification ${ }^{81}$. Genome modification using site-specific nucleases and removal of vector sequences by crossing, or use of vector-free approaches, has been accepted in some agencies not requiring regulation as a transgenic event. However, acceptance has not been universally accepted. Regardless of regulatory issues, our understanding of plant resistance mechanisms has increased considerably in the last five years, and new insights into defenses against resistance that incorporate abiotic and other physiological pathways of plants will undoubtedly be forthcoming. The discoveries will inform mutational and traditional breeding strategies in the absence of adoption of gene transfer or gene editing technologies and help meet the future needs for food output for a growing world population and climate-challenged food production system. 
1. $\quad F$ Tang D, Wang G, Zhou JM: Receptor Kinases in Plant-Pathogen Interactions: More Than Pattern Recognition. Plant Cell. 2017; 29(4): 618-37. PubMed Abstract | Publisher Full Text | Free Full Text | F1000 Recommendation

2. Zipfel C, Kunze G, Chinchilla D, et al:: Perception of the bacterial PAMP EF-Tu by the receptor EFR restricts Agrobacterium-mediated transformation. Cell. 2006; 125(4): 749-60.

PubMed Abstract | Publisher Full Text

3. F Lacombe S, Rougon-Cardoso A, Sherwood E, et al.: Interfamily transfer of a plant pattern-recognition receptor confers broad-spectrum bacterial resistance. Nat Biotechnol. 2010; 28(4): 365-9.

PubMed Abstract | Publisher Full Text | F1000 Recommendation

4. Kunwar S, Iriarte F, Fan Q, et al:: Transgenic Expression of EFR and Bs2 Genes for Field Management of Bacterial Wilt and Bacterial Spot of Tomato. Phytopathology. 2018; 108(12): 1402-11.

PubMed Abstract | Publisher Full Text

5. F Boschi F, Schvartzman C, Murchio S, et al.: Enhanced Bacterial Wilt Resistance in Potato Through Expression of Arabidopsis EFR and Introgression of Quantitative Resistance from Solanum commersonii. Front Plant Sci. 2017; 8: 1642

PubMed Abstract | Publisher Full Text | Free Full Text | F1000 Recommendation

6. Schoonbeek HJ, Wang HH, Stefanato FL, et al:: Arabidopsis EF-Tu receptor enhances bacterial disease resistance in transgenic wheat. New Phytol. 2015; 206(2): 606-13.

PubMed Abstract | Publisher Full Text

7. Lu $\mathrm{F}$, Wang $\mathrm{H}$, Wang $\mathrm{S}$, et al.: Enhancement of innate immune system in monocot rice by transferring the dicotyledonous elongation factor Tu receptor EFR. J Integr Plant Biol. 2015; 57(7): 641-52.

PubMed Abstract | Publisher Full Text

8. Schwessinger $\mathrm{B}, \mathrm{Bahar} \mathrm{O}$, Thomas $\mathrm{N}$, et al.: Transgenic expression of the dicotyledonous pattern recognition receptor EFR in rice leads to liganddependent activation of defense responses. PLoS Pathog. 2015; 11(3): e1004809.

PubMed Abstract | Publisher Full Text | Free Full Text

9. Hao G, Pitino M, Duan $Y$, et al:: Reduced Susceptibility to Xanthomonas citri in Transgenic Citrus Expressing the FLS2 Receptor From Nicotiana benthamiana. Mol Plant Microbe Interact. 2016; 29(2): 132-42. PubMed Abstract | Publisher Full Text

10. F Liu F, McDonald M, Schwessinger B, et al:: Variation and inheritance of the Xanthomonas raxX-raxSTAB gene cluster required for activation of XA21-mediated immunity. Mol Plant Pathol. 2019; 20(5): 656-72. PubMed Abstract | Publisher Full Text | Free Full Text | F1000 Recommendation

11. F Pruitt RN, Joe A, Zhang W, et al.: A microbially derived tyrosine-sulfated peptide mimics a plant peptide hormone. New Phytol. 2017; 215(2): 725-36. PubMed Abstract | Publisher Full Text | Free Full Text | F1000 Recommendation

12. Tripathi JN, Lorenzen J, Bahar $\mathrm{O}$, et al.: Transgenic expression of the rice Xa21 pattern-recognition receptor in banana (Musa sp.) confers resistance to Xanthomonas campestris pv. musacearum. Plant Biotechnol J. 2014; 12(6): 663-73.

PubMed Abstract | Publisher Full Text | Free Full Text

13. Macho AP, Zipfel C: Targeting of plant pattern recognition receptor-triggered immunity by bacterial type-III secretion system effectors. Curr Opin Microbiol. 2015; 23: 14-22.

PubMed Abstract | Publisher Full Text

14. Horvath DM, Pauly MH, Hutton SF, et al.: The pepper BS2 gene confers effective field resistance to bacterial leaf spot and yield enhancement in Florida tomatoes. Acta Hortic. 2015; 47-51.

Publisher Full Text

15. F Dale J, James A, Paul JY, et al:: Transgenic Cavendish bananas with resistance to Fusarium wilt tropical race 4. Nat Commun. 2017; 8(1): 1496. PubMed Abstract | Publisher Full Text | Free Full Text | F1000 Recommendation

16. Kawashima CG, Guimarães GA, Nogueira SR, et al:: A pigeonpea gene confers resistance to Asian soybean rust in soybean. Nat Biotechnol. 2016; 34(6): 661-5. PubMed Abstract | Publisher Full Text

17. Jupe F, Witek K, Verweij W, et al.: Resistance gene enrichment sequencing (RenSeq) enables reannotation of the NB-LRR gene family from sequenced plant genomes and rapid mapping of resistance loci in segregating populations. Plant J. 2013; 76(3): 530-44.

PubMed Abstract | Publisher Full Text | Free Full Text

18. F Arora S, Steuernagel B, Gaurav K, et al:: Resistance gene cloning from a wild crop relative by sequence capture and association genetics. $\mathrm{Nat}$ Biotechnol. 2019; 37(2): 139-43.

PubMed Abstract | Publisher Full Text | F1000 Recommendation

19. Steuernagel B, Periyannan SK, Hernández-Pinzón I, et al.: Rapid cloning of disease-resistance genes in plants using mutagenesis and sequence capture. Nat Biotechnol. 2016; 34(6): 652-5. PubMed Abstract | Publisher Full Text

20. F Schultink A, Qi T, Lee A, et al.: Roq1 mediates recognition of the
Xanthomonas and Pseudomonas effector proteins XopQ and HopQ1. Plant $J$. 2017; 92(5): 787-95.

PubMed Abstract | Publisher Full Text | F1000 Recommendation

21. Timilsina S, Abrahamian $P$, Potnis N, et al:: Analysis of Sequenced Genomes of Xanthomonas perforans Identifies Candidate Targets for Resistance Breeding in Tomato. Phytopathology. 2016; 106(10): 1097-104.

PubMed Abstract | Publisher Full Text

22. F Kamoun S, Talbot NJ, Islam MT: Plant health emergencies demand open science: Tackling a cereal killer on the run. PLOS Biol. 2019; 17(6): e3000302. PubMed Abstract | Publisher Full Text | Free Full Text | F1000 Recommendation

23. F Adachi H, Derevnina L, Kamoun S: NLR singletons, pairs, and networks: evolution, assembly, and regulation of the intracellular immunoreceptor circuitry of plants. Curr Opin Plant Biol. 2019; 50: 121-31.

PubMed Abstract | Publisher Full Text | F1000 Recommendation

24. Cesari S, Bernoux M, Moncuquet $\mathrm{P}$, et al:: A novel conserved mechanism for plant NLR protein pairs: the "integrated decoy" hypothesis. Front Plant Sci. 2014; 5: 606.

PubMed Abstract | Publisher Full Text | Free Full Text

25. Narusaka M, Shirasu K, Noutoshi $Y$, et al:: RRS1 and RPS4 provide a dual Resistance-gene system against fungal and bacterial pathogens. Plant J. 2009; 60(2): 218-26.

PubMed Abstract | Publisher Full Text

26. Narusaka M, Kubo Y, Hatakeyama K, et al:: Interfamily transfer of dual NB-LRR genes confers resistance to multiple pathogens. PLoS One. 2013; 8(2): e55954. PubMed Abstract | Publisher Full Text | Free Full Text

27. Ade J, DeYoung BJ, Golstein C, et al:: Indirect activation of a plant nucleotide binding site-leucine-rich repeat protein by a bacterial protease. Proc Natl Acad Sci U S A. 2007; 104(7): 2531-6.

PubMed Abstract | Publisher Full Text | Free Full Text

28. Kim SH, Qi D, Ashfield T, et al.: Using decoys to expand the recognition specificity of a plant disease resistance protein. Science. 2016; 351(6274): 684-7. PubMed Abstract | Publisher Full Text

29. F De la Concepcion JC, Franceschetti M, Maqbool A, et al:: Polymorphic residues in rice NLRs expand binding and response to effectors of the blast pathogen. Nat Plants. 2018; 4(8): 576-85.

PubMed Abstract | Publisher Full Text | F1000 Recommendation

30. Chapman S, Stevens LJ, Boevink PC, et al.: Detection of the virulent form of AVR3a from Phytophthora infestans following artificial evolution of potato resistance gene R3a. PLoS One. 2014; 9(10): e110158. PubMed Abstract | Publisher Full Text | Free Full Text

31. Giannakopoulou A, Steele JF, Segretin ME, et al:: Tomato I2 Immune Receptor Can Be Engineered to Confer Partial Resistance to the Oomycete Phytophthora infestans in Addition to the Fungus Fusarium oxysporum. Mol Plant Microbe Interact. 2015; 28(12): 1316-29. PubMed Abstract | Publisher Full Text

32. $\mathrm{F}$ Wang J, Wang J, Hu M, et al.: Ligand-triggered allosteric ADP release primes a plant NLR complex. Science. 2019; 364(6435). pii: eaav5868. PubMed Abstract | Publisher Full Text | F1000 Recommendation

33. F Wang J, Hu M, Wang J, et al.: Reconstitution and structure of a plant NLR resistosome conferring immunity. Science. 2019; 364(6435): pii: eaav5870 PubMed Abstract | Publisher Full Text | F1000 Recommendation

34. $\mathrm{F}$ Tripathi $\mathrm{L}$, Atkinson $\mathrm{H}$, Roderick $\mathrm{H}$, et al:: Genetically engineered bananas resistant to Xanthomonas wilt disease and nematodes. Food Energy Secur. 2017; $6(2): 37-47$

PubMed Abstract | Publisher Full Text | Free Full Text | F1000 Recommendation

35. Breen S, Solomon PS, Bedon F, et al:: Surveying the potential of secreted antimicrobial peptides to enhance plant disease resistance. Front Plant $\mathrm{S} c i$. 2015; 6: 900.

PubMed Abstract | Publisher Full Text | Free Full Text

36. Bundó $\mathrm{M}$, Montesinos L, Izquierdo E, et al:: Production of cecropin $\mathbf{A}$ antimicrobial peptide in rice seed endosperm. BMC Plant Biol. 2014; 14: 102 PubMed Abstract | Publisher Full Text | Free Full Text

37. $\mathrm{F}$ Zou $\mathrm{X}$, Jiang $\mathrm{X}, \mathrm{Xu} \mathrm{L}$, et al:: Transgenic citrus expressing synthesized cecropin $B$ genes in the phloem exhibits decreased susceptibility to Huanglongbing. Plant Mol Biol. 2017; 93(4-5): 341-53.

PubMed Abstract | Publisher Full Text | F1000 Recommendation

38. Herrera Diaz A, Kovacs I, Lindermayr C: Inducible Expression of the De-Novo Designed Antimicrobial Peptide SP1-1 in Tomato Confers Resistance to Xanthomonas campestris pv. vesicatoria. PLoS One. 2016; 11(10): e0164097. PubMed Abstract | Publisher Full Text | Free Full Text

39. Lindow S, Newman K, Chatterjee S, et al:: Production of Xylella fastidiosa diffusible signal factor in transgenic grape causes pathogen confusion and reduction in severity of Pierce's disease. Mol Plant Microbe Interact. 2014; 27(3): 244-54. PubMed Abstract | Publisher Full Text

40. F Caserta R, Souza-Neto RR, Takita MA, et al.: Ectopic Expression of Xylella fastidiosa rpfF Conferring Production of Diffusible Signal Factor in Transgenic Tobacco and Citrus Alters Pathogen Behavior and Reduces Disease Severity. 
Mol Plant Microbe Interact. 2017; 30(11): 866-75.

PubMed Abstract | Publisher Full Text | F1000 Recommendation

41. F Borrelli VMG, Brambilla V, Rogowsky $P$, et al:: The Enhancement of Plant Disease Resistance Using CRISPR/Cas9 Technology. Front Plant Sci. 2018; 9: 1245. PubMed Abstract | Publisher Full Text | Free Full Text | F1000 Recommendation

42. F Kusch S, Panstruga R: mlo-Based Resistance: An Apparently Universal "Weapon" to Defeat Powdery Mildew Disease. Mol Plant Microbe Interact. 2017; 30(3): 179-89.

PubMed Abstract | Publisher Full Text | F1000 Recommendation

43. $F$ Wang $Y$, Cheng $X$, Shan $Q$, et al:: Simultaneous editing of three homoeoalleles in hexaploid bread wheat confers heritable resistance to powdery mildew. Nat Biotechnol. 2014; 32(9): 947-51.

PubMed Abstract | Publisher Full Text | F1000 Recommendation

44. Zeilmaker T, Ludwig NR, Elberse J, et al:: DOWNY MILDEW RESISTANT 6 and DMR6-LIKE OXYGENASE 1 are partially redundant but distinct suppressors of immunity in Arabidopsis. Plant J. 2015; 81(2): 210-22. PubMed Abstract | Publisher Full Text

45. de Toledo Thomazella DP, Brail Q, Dahlbeck D, et al.: CRISPR-Cas9 mediated mutagenesis of a DMR6 ortholog in tomato confers broad-spectrum disease resistance. bioRxiv. 2016. Publisher Full Text

46. F Xu G, Yuan M, Ai C, et al.: uORF-mediated translation allows engineered plant disease resistance without fitness costs. Nature. 2017; 545(7655): 491-4. PubMed Abstract | Publisher Full Text | Free Full Text | F1000 Recommendation

47. F Silva KJP, Mahna N, Mou Z, et al:: NPR1 as a transgenic crop protection strategy in horticultural species. Hortic Res. 2018; 5: 15. PubMed Abstract | Publisher Full Text | Free Full Text | F1000 Recommendation

48. Jia H, Zhang $\mathrm{Y}$, Orbović V, et al.: Genome editing of the disease susceptibility gene CsLOB1 in citrus confers resistance to citrus canker. Plant Biotechnol J. 2017; 15(7): 817-23.

PubMed Abstract | Publisher Full Text | Free Full Text

49. Jia H, Orbovic V, Jones JB, et al.: Modification of the PthA4 effector binding elements in Type I CsLOB1 promoter using Cas9/sgRNA to produce transgenic Duncan grapefruit alleviating Xcc $\Delta$ pthA4:dCsLOB1.3 infection. Plant Biotechnol J. 2016; 14(5): 1291-301.

PubMed Abstract | Publisher Full Text

50. F Peng A, Chen S, Lei T, et al.: Engineering canker-resistant plants through CRISPR/Cas9-targeted editing of the susceptibility gene CsLOB1 promoter in citrus. Plant Biotechnol J. 2017; 15(12): 1509-19.

PubMed Abstract | Publisher Full Text | Free Full Text | F1000 Recommendation

51. F Li T, Liu B, Spalding MH, et al:: High-efficiency TALEN-based gene editing produces disease-resistant rice. Nat Biotechnol. 2012; 30(5): 390-2. PubMed Abstract | Publisher Full Text | F1000 Recommendation

52. Cao H, Li X, Dong X: Generation of broad-spectrum disease resistance by overexpression of an essential regulatory gene in systemic acquired resistance. Proc Natl Acad Sci U S A. 1998; 95(11): 6531-6. PubMed Abstract | Publisher Full Text | Free Full Text

53. F Blanvillain-Baufumé S, Reschke M, Solé M, et al:: Targeted promoter editing for rice resistance to Xanthomonas oryzae pv. oryzae reveals differential activities for SWEET14-inducing TAL effectors. Plant Biotechnol J. 2017; 15(3): 306-17. PubMed Abstract | Publisher Full Text | Free Full Text | F1000 Recommendation

54. Zhou J, Peng Z, Long J, et al:: Gene targeting by the TAL effector PthXo2 reveals cryptic resistance gene for bacterial blight of rice. Plant J. 2015; 82(4): 632-43. PubMed Abstract | Publisher Full Text

55. Oliva R, Ji C, Atienza-Grande G, et al.: Broad-spectrum resistance to bacteria blight in rice using genome editing. Nat Biotechnol. 2019.

56. F Zaidi SS, Mukhtar MS, Mansoor S: Genome Editing: Targeting Susceptibility Genes for Plant Disease Resistance. Trends Biotechnol. 2018; 36(9): 898-906. PubMed Abstract | Publisher Full Text | F1000 Recommendation

57. F Ali Z, Zaidi SS, Tashkandi M, et al:: A Simplified Method to Engineer CRISPR/Cas9-Mediated Geminivirus Resistance in Plants. Methods Mol Biol. 2019; 2028: 167-83.

PubMed Abstract | Publisher Full Text | F1000 Recommendation

58. F Ma J, Chen J, Wang M, et al.: Disruption of OsSEC3A increases the conten of salicylic acid and induces plant defense responses in rice. $J$ Exp Bot. 2018; 69(5): 1051-64.

PubMed Abstract | Publisher Full Text | Free Full Text | F1000 Recommendation

59. F Acevedo-Garcia J, Spencer $\mathrm{D}$, Thieron $\mathrm{H}$, et al.: mlo-based powdery mildew resistance in hexaploid bread wheat generated by a non-transgenic TILLING approach. Plant Biotechnol J.2017; 15(3): 367-78.

PubMed Abstract | Publisher Full Text | Free Full Text | F1000 Recommendation

60. Hummel AW, Doyle EL, Bogdanove AJ: Addition of transcription activatorlike effector binding sites to a pathogen strain-specific rice bacterial blight resistance gene makes it effective against additional strains and against bacterial leaf streak. New Phytol. 2012; 195(4): 883-93.

PubMed Abstract | Publisher Full Text

61. Zeng X, Tian D, Gu K, et al.: Genetic engineering of the Xa10 promoter for broad-spectrum and durable resistance to Xanthomonas oryzae pv. oryzae. Plant Biotechnol J. 2015; 13(7): 993-1001.

PubMed Abstract | Publisher Full Text

62. Hutin M, Césari S, Chalvon V, et al.: Ectopic activation of the rice NLR heteropair RGA4/RGA5 confers resistance to bacterial blight and bacterial leaf streak diseases. Plant J. 2016; 88(1): 43-55.

PubMed Abstract | Publisher Full Text

63. Shantharaj D, Römer P, Figueiredo JFL, et al:: An engineered promoter driving expression of a microbial avirulence gene confers recognition of TAL effectors and reduces growth of diverse Xanthomonas strains in citrus. Mol Plant Pathol. 2017; 18(7): 976-89.

PubMed Abstract | Publisher Full Text | Free Full Text

64. Robaglia C, Caranta C: Translation initiation factors: a weak link in plant RNA virus infection. Trends Plant Sci. 2006; 11(1): 40-5. PubMed Abstract | Publisher Full Text

65. Pyott DE, Sheehan E, Molnar A: Engineering of CRISPR/Cas9-mediated potyvirus resistance in transgene-free Arabidopsis plants. Mol Plant Pathol. 2016; 17(8): 1276-88.

PubMed Abstract | Publisher Full Text | Free Full Text

66. Chandrasekaran J, Brumin M, Wolf D, et al: Development of broad virus resistance in non-transgenic cucumber using CRISPR/Cas9 technology. Mol Plant Pathol. 2016; 17(7): 1140-53.

PubMed Abstract | Publisher Full Text | Free Full Text

67. Gauffier C, Lebaron C, Moretti A, et al: A TILLING approach to generate broadspectrum resistance to potyviruses in tomato is hampered by eIF4E gene redundancy. Plant J. 2016; 85(6): 717-29. PubMed Abstract | Publisher Full Text

68. F Bastet A, Robaglia C, Gallois JL: elF4E Resistance: Natural Variation Should Guide Gene Editing. Trends Plant Sci. 2017; 22(5): 411-9. PubMed Abstract | Publisher Full Text | F1000 Recommendation

69. Zaidi SS, Tashkandi M, Mansoor S, et al:: Engineering Plant Immunity: Using CRISPR/Cas9 to Generate Virus Resistance. Front Plant Sci. 2016; 7: 1673. PubMed Abstract | Publisher Full Text | Free Full Text

70. Baltes NJ, Hummel AW, Konecna E, et al:: Conferring resistance to geminiviruses with the CRISPR-Cas prokaryotic immune system. Nat Plants. 2015; 1: 15145. Publisher Full Text

71. Ji X, Zhang $\mathrm{H}$, Zhang $\mathrm{Y}$, et al.: Establishing a CRISPR-Cas-like immune system conferring DNA virus resistance in plants. Nat Plants. 2015; 1: 15144 PubMed Abstract | Publisher Full Text

72. Iqbal Z, Sattar MN, Shafiq M: CRISPR/Cas9: A Tool to Circumscribe Cotton Leaf Curl Disease. Front Plant Sci. 2016; 7: 475. PubMed Abstract | Publisher Full Text | Free Full Text

73. F Moore JW, Herrera-Foessel S, Lan C, et al:: A recently evolved hexose transporter variant confers resistance to multiple pathogens in wheat. Nat Genet. 2015; 47(12): 1494-8.

PubMed Abstract | Publisher Full Text | F1000 Recommendation

74. $\mathrm{F}$ Krattinger SG, Lagudah ES, Spielmeyer W, et al: A putative ABC transporter confers durable resistance to multiple fungal pathogens in wheat. Science. 2009; 323(5919): 1360-3.

PubMed Abstract | Publisher Full Text | F1000 Recommendation

75. F Milne RJ, Dibley KE, Schnippenkoetter W, et al:: The Wheat Lr67 Gene from the Sugar Transport Protein 13 Family Confers Multipathogen Resistance in Barley. Plant Physiol. 2019; 179(4): 1285-97.

PubMed Abstract | Publisher Full Text | Free Full Text | F1000 Recommendation

76. Risk JM, Selter LL, Chauhan $\mathrm{H}$, et al:: The wheat $\mathrm{Lr} 34$ gene provides resistance against multiple fungal pathogens in barley. Plant Biotechnol J. 2013; 11(7): 847-54.

PubMed Abstract | Publisher Full Text

77. F Schnippenkoetter W, Lo C, Liu G, et al.: The wheat Lr34 multipathogen resistance gene confers resistance to anthracnose and rust in sorghum. Plant Biotechnol J. 2017; 15(11): 1387-96.

PubMed Abstract | Publisher Full Text | Free Full Text | F1000 Recommendation

78. Chauhan $\mathrm{H}$, Boni $\mathrm{R}$, Bucher $\mathrm{R}$, et al.: The wheat resistance gene $\mathrm{Lr} 34$ results in the constitutive induction of multiple defense pathways in transgenic barley. Plant J. 2015; 84(1): 202-15.

PubMed Abstract | Publisher Full Text

79. Krattinger SG, Sucher J, Selter LL, et al:: The wheat durable, multipathogen resistance gene $L r 34$ confers partial blast resistance in rice. Plant Biotechnol J. 2016; 14(5): 1261-8.

PubMed Abstract | Publisher Full Text

80. $\mathrm{F}$ Krattinger SG, Kang J, Bräunlich S, et al:: Abscisic acid is a substrate of the ABC transporter encoded by the durable wheat disease resistance gene Lr34. New Phytol. 2019; 223(2): 853-66.

PubMed Abstract | Publisher Full Text | Free Full Text | F1000 Recommendation

81. Cardi T, Varshney R: Cisgenesis and genome editing: Combining concepts and efforts for a smarter use of genetic resources in crop breeding. Plant Breed. 2016; 135(2): 139-47.

Publisher Full Text 


\section{Open Peer Review}

\section{Current Peer Review Status:}

\section{Editorial Note on the Review Process}

Faculty Reviews are review articles written by the prestigious Members of Faculty Opinions. The articles are commissioned and peer reviewed before publication to ensure that the final, published version is comprehensive and accessible. The reviewers who approved the final version are listed with their names and affiliations.

\section{The reviewers who approved this article are:}

\section{Version 1}

\section{Magdy M Mahfouz}

Laboratory for Genome Engineering, Division of Environmental and Biological Sciences and Engineering, King Abdullah University of Science and Technology, Thuwal, Saudi Arabia Competing Interests: No competing interests were disclosed.

\section{Zuhua He}

National Key Laboratory of Plant Molecular Genetics, CAS Center for Excellence in Molecular Plant Sciences/Shanghai Institute of Plant Physiology \& Ecology, Chinese Academy of Sciences, Shanghai, China

Competing Interests: No competing interests were disclosed.

The benefits of publishing with F1000Research:

- Your article is published within days, with no editorial bias

- You can publish traditional articles, null/negative results, case reports, data notes and more

- The peer review process is transparent and collaborative

- Your article is indexed in PubMed after passing peer review

- Dedicated customer support at every stage

For pre-submission enquiries, contact research@f1000.com 